\title{
Insulin Secretion from Pancreatic Islets: Effect of Growth Hormone and Related Proteins
}

\author{
B. A. Larson, T. L. Williams, U. J. Lewis, and W. P. VanderLaan \\ Lutcher Brown Center for Diabetes and Endocrinology, Scripps Clinic and Research Foundation, La Jolla, California, USA
}

Summary. Insulin responses to clinical grade human growth hormone ( $\mathrm{hGH}$ ), intact $\mathrm{hGH}$, naturally occurring diabetogenic substance (NDS), and subtilisin cleaved forms of hGH $\left(S_{1}\right.$ and $\left.S_{3}\right)$ were studied using hypophysectomized rat pancreatic islets. While clinical grade $\mathrm{hGH}(200 \mu \mathrm{g} / \mathrm{ml})$ elicited a prompt and sustained release of insulin, purified intact hGH (200 $\mu \mathrm{g} / \mathrm{ml}$ ) did not. Naturally occurring diabetogenic sub stance, isolated from clinical grade hGH preparations, stimulated insulin release at $200 \mathrm{ng} / \mathrm{ml}$. Upon repeat stimulation with NDS, a significantly greater insulin release than with initial stimulation was observed. Although $S_{3}(200 \mu \mathrm{g} / \mathrm{ml})$ elicited significant insulin release, $S_{1}(200 \mu \mathrm{g} / \mathrm{ml})$ did not. Direct stimulation of insulin release with clinical grade $\mathrm{hGH}$ is not due to intact hGH but another protein(s) such as NDS. Enzymic modification of intact hGH appears to enhance insulin stimulatory capacity.

Key words: Insulin release, pancreatic islets, human growth hormone (hGH), pituitary diabetogenic substance.

Previous reports have reached differing conclusions regarding the acute in vitro effects of growth hormone on insulin secretion [1-5]. With recent advances in protein isolation and purification, it has become possible to define more clearly the structural and functional properties of human growth hormone. As it is isolated conventionally from the pituitary, hGH is actually a family of proteins [6] each of which may possess unique functional characteristics [7]. It is therefore not surprising that varying preparations of growth hormone used by different investigators have given disparate results.
More recently, our laboratory has isolated from clinical grade $\mathrm{hGH}$ a naturally occurring diabetogenic substance (NDS) which produces glucose intolerance and hyperinsulinaemia in the dog. Limited hydrolysis of purified hGH (intact hGH) with subtilisin results in two-chain modifications of hGH designated as $S_{1}, S_{2}$, and $S_{3}$. The subtilisin cleaved form, $S_{1}$, is the most active of the three in producing hyperlgycaemia and hyperinsulinaemia in the dog [8].

This study was initiated to determine what effect clinical grade hGH, intact $\mathrm{hGH}$, and NDS have on insulin secretion. We further wished to determine whether enzymically modified forms of intact $\mathrm{hGH}$, $S_{1}$ and $S_{3}$, had a greater capacity than intact hGH to induce insulin secretion from isolated islets.

\section{Materials and Methods}

\begin{abstract}
Animals
Hypophysectomized adult female Long Evans rats were purchased from Simonsen Laboratories, Inc. (Gilroy, Calif.). At least three weeks were allowed to lapse between hyophysectomy and use in this study. Rats weighed from 100 to $156 \mathrm{~g}$ and were fed a high sucrose, low starch diet (ICN Pharmaceuticals, Inc., Cleveland, Ohio) ad libitum.
\end{abstract}

\section{Experimental Procedures}

Islets of Langerhans were isolated by collagenase digestion [9-10] from two rats following pentobarbital anaesthesia. Following mincing, pancreata were digested in Hank's solution containing collagenase (type IV, Worthington Biochemical Corp., Freehold, N.J.). After digestion was complete, the islets were washed 6 times with Hank's solution and then were isolated within $1 \mathrm{~h}$ with the use of a dissecting microscope and a fine bore siliconized pipette; (100-400 islets were obtained from two pancreata).

Islets were placed within perifusion chambers (Millipore plastic filtration units, [Millipore Corp., Bedford, Mass.], $1.0 \mathrm{ml}$ capacity) and were perifused with Krebs-Ringer bicarbonate (KRB) solution as previously described [11]. The dead space of the entire system was $1.8 \mathrm{ml}$, and the flow rate was $1.0 \pm 0.1 \mathrm{ml} / \mathrm{min}$. For the initial $50 \mathrm{~min}$ islets were perifused with $\mathrm{KRB}$ containing $0.5 \mathrm{mg} / \mathrm{ml}$ 


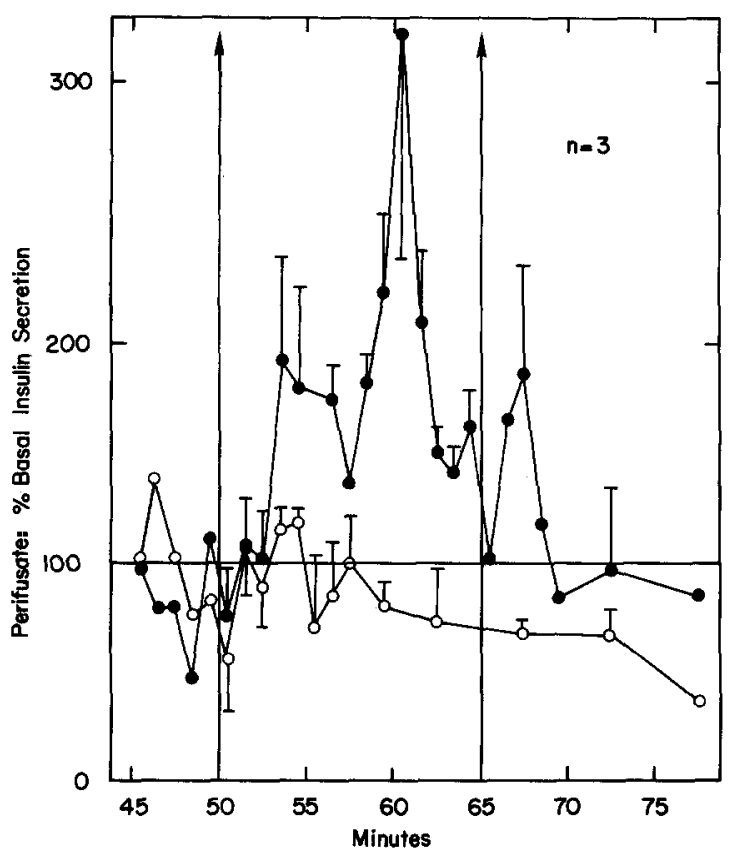

Fig. 1. Effect of clinical grade hGH (CGhGH) $200 \mu \mathrm{g} / \mathrm{ml}$ on insulin release. Double chambers were used. Islets in both chambers were perifused with KRB- $0.5 \mathrm{mg} / \mathrm{ml}$ glucose. Insulin release from the control $(\mathrm{O}-\mathrm{O})$ chamber corresponding to $100 \%$ basal was 2.6 \pm 0.3 and from the experimental $(-)$ chamber, $2.5 \pm 0.2 \mu \mathrm{U} /$ $\mathrm{ml} / \mathrm{min} / 25$ islets (mean $\pm \mathrm{SEM}$ ). From 51 through $65 \mathrm{~min}$ the control chamber was perifused with the same solution, but the experimental chamber was perifused with solution containing 200 $\mu \mathrm{g} / \mathrm{ml}$ CGhGH. After $65 \mathrm{~min}$ both chambers were changed to fresh $\mathrm{KRB}$ with $0.5 \mathrm{mg} / \mathrm{ml}$ glucose. Each point represents the mean of three separate experiments. Vertical bars indicate SEM

glucose; a basal efflux of insulin was achieved from 40 through 50 $\mathrm{min}$, and perifusion collection began after $40 \mathrm{~min}$. At $50 \mathrm{~min}$ the inlet of one or more of the perifusion channels was transferred with a three way valve (Hamilton Co., Reno, Nev.) to a KRB solution containing $0.5 \mathrm{mg} / \mathrm{ml}$ glucose plus a test substance while the inlet of the control channel was changed to fresh KRB containing only $0.5 \mathrm{mg} / \mathrm{ml}$ glucose.

The hGH preparations and NDS were prepared in our laboratory [8]. "Clinical grade hGH" is defined as being fraction 2 following chromatography of crude hGH on a Sephadex G-50 column. "Intact hGH" is single chain, monomeric hGH of 191 amino acids found in fraction 3 after DEAE-cellulose chromatography. "Naturally occurring diabetogenic substance" is material prepared from clinical grade hGH by DEAE-cellulose chromatography and is found in fractions 5 and 6 . Subtilisin cleaved forms were prepared from intact $h \mathrm{hH}, \mathrm{S}_{1}$ has amino acids $150-158$ missing while $\mathrm{S}_{3}$ has amino acids 147-158 missing. Each peptide used in these experiments was dissolved shortly before use in $0.05 \mathrm{~mol} / \mathrm{l}$ carbonate-bicarbonate buffer, $\mathrm{pH} \mathrm{10,} \mathrm{and} \mathrm{then} \mathrm{added} \mathrm{to} \mathrm{KRB} \mathrm{solution.}$ Correction of $\mathrm{pH}$ to 7.4 was accomplished with $0.3 \mathrm{~mol} / 1 \mathrm{HCl}$.

\section{Assays}

In the experiments presented here the amount of protein in each sample of pituitary extract was determined by the method of Har-

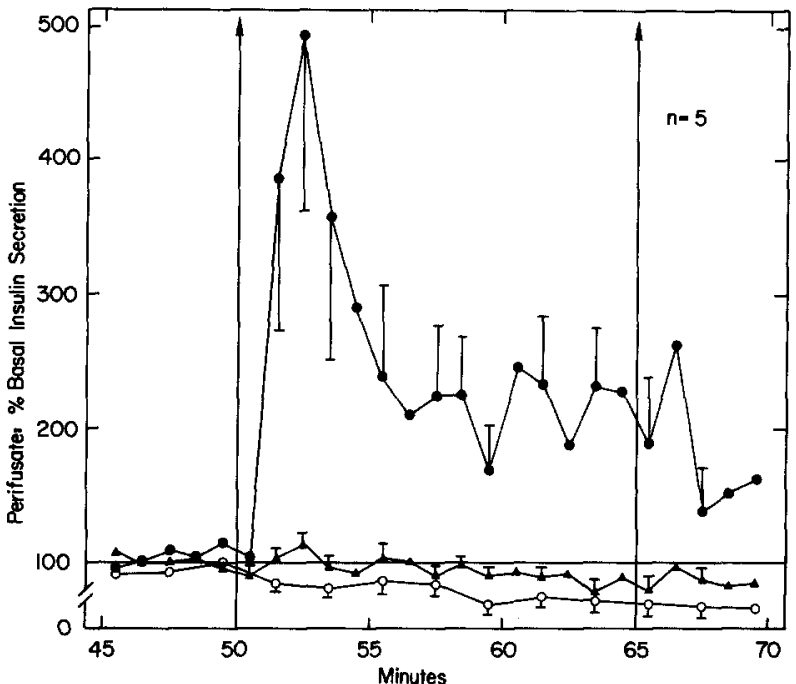

Fig. 2. Effect of intact hGH $200 \mu \mathrm{g} / \mathrm{ml}$ and naturally occurring diabetogenic substance (NDS) $200 \mu \mathrm{g} / \mathrm{ml}$ during islet perifusion. Three chambers were perifused simultaneously. Until $51 \mathrm{~min}$ and after $65 \mathrm{~min}$ chambers were perifused with $\mathrm{KRB}-0.5 \mathrm{mg} / \mathrm{ml}$ glucose. From 51 through 65 min one chamber $\left(O_{-} \mathrm{O}\right)$ was perifused with $\mathrm{KRB}-0.5 \mathrm{mg} / \mathrm{ml}$ glucose while the second (-) was perifused with KRB- $0.5 \mathrm{mg} / \mathrm{ml}$ glucose plus NDS $200 \mu \mathrm{g} / \mathrm{ml}$. The third (A-A) was perifused with $\mathrm{KRB}-0.5 \mathrm{mg} / \mathrm{ml}$ glucose and intact hGH $200 \mu \mathrm{g} / \mathrm{ml}$. Insulin release from the control chamber corresponding to $100 \%$ basal was $3.9 \pm 0.2$; the second, $4.1 \pm 0.2$; and the third, $3.4 \pm 0.2 \mu \mathrm{U} / \mathrm{ml} / \mathrm{min} / 25$ islets (mean \pm SEM). Each point represents the mean from 5 separate experiments. Vertical bars indicate SEM

tree [12] with bovine serum albumin (Armour Pharmaceutical Co., Kankakee, Ill.) as standard.

A double antibody radioimmunoassay was employed to determine total immunologically reactive insulin [13] using rat insulin standards (Novo Research Institute, Bagsvaerd, Denmark) and guinea pig anti-porcine insulin antiserum (Miles Laboratory, Elkhart, Ind.). Goat anti-guinea pig gamma globulin (Antibodies, Inc., Davis, Calif.) was used as second antibody. Each sample was assayed in triplicate.

Insulin release from islets was expressed as the percent of mean basal insulin $(\mu \mathrm{U} / \mathrm{ml})$ released each min from islets during the 40th to 50 th $\mathrm{min}$ of perifusion. Differences in total insulin release during the test period(s) were compared by analysis of variance [14].

\section{Results}

\section{Study with Clinical Grade hGH}

Perifusion with medium containing $200 \mu \mathrm{g} / \mathrm{ml}$ clinical grade hGH resulted in an immediate release of insulin (Fig. 1), which persisted for as long as exposure continued, and was significantly greater $(\mathrm{P}<0.0005)$ than the efflux of insulin from the control channel. 


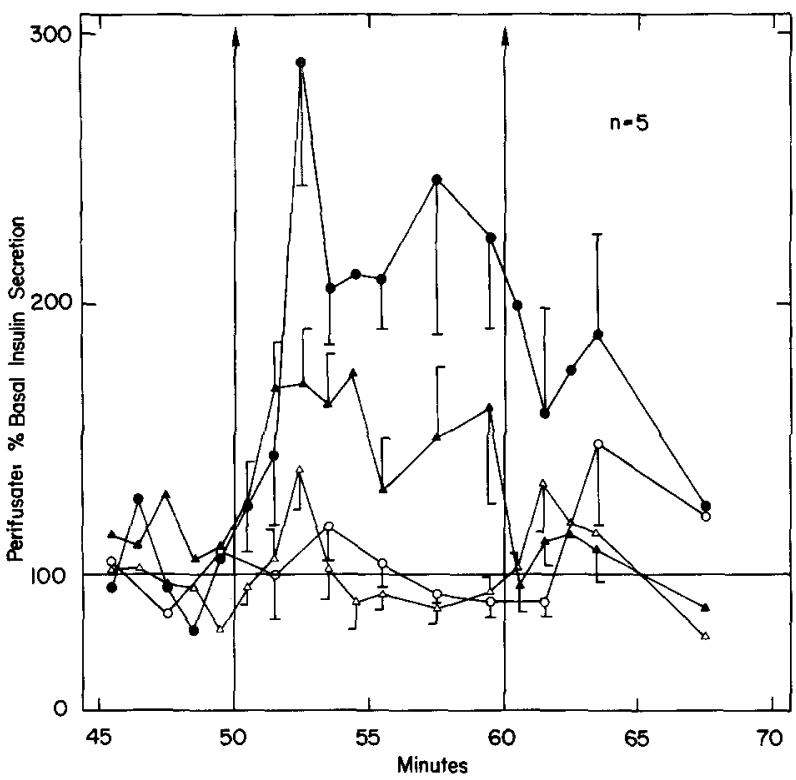

Fig. 3. Effect of varying doses of naturally occurring diabetogenic substance (NDS) on insulin release. Four chambers were perifused through $50 \mathrm{~min}$ and after $60 \mathrm{~min}$ with $\mathrm{KRB}-0.5 \mathrm{mg} / \mathrm{ml}$ glucose. From 51 through $60 \mathrm{~min}$ control channel $(\mathrm{O}-\mathrm{O})$ was perifused with KRB- $0.5 \mathrm{mg} / \mathrm{ml}$ glucose, the second (-) with solution containing NDS $200 \mu \mathrm{g} / \mathrm{ml}$, the third $(\boldsymbol{\Delta}-\boldsymbol{\Delta})$ with NDS $200 \mathrm{ng} /$ $\mathrm{ml}$, and the fourth $(\triangle-\triangle)$ with NDS $0.2 \mathrm{ng} / \mathrm{ml}$. Insulin release from the control chamber equivalent to $100 \%$ basal was $6.8 \pm 0.8$; the second, $9.0 \pm 0.8$; the third, $14.8 \pm 1.6$; and the fourth, $9.4 \pm$ $1.0 \mu \mathrm{U} / \mathrm{ml} / \mathrm{min} / 25$ islets (mean $\pm \mathrm{SEM}$ ). Mean values from 5 separate experiments are presented. Vertical bars indicate SEM

\section{Studies with Naturally Occurring Diabetogenic Substance}

Figure 2 shows the islet response to intact hGH and NDS. Whereas intact hGH did not induce a significant release of insulin, NDS did $(\mathrm{P}<0.0005)$. The concentration of both proteins was $200 \mu \mathrm{g} / \mathrm{ml}$.

Figure 3 shows the insulin release in response to 0.2 and $200 \mathrm{ng} / \mathrm{ml}$ and $200 \mu \mathrm{g} / \mathrm{ml}$ NDS. Although the responses to $200 \mathrm{ng} / \mathrm{ml}$ and $200 \mu \mathrm{g} / \mathrm{ml}$ were significant $(\mathrm{P}<0.0005)$, the response to $0.2 \mathrm{ng} / \mathrm{ml}$ was not.

When islets were exposed to NDS $(200 \mu \mathrm{g} / \mathrm{ml})$ for $10 \mathrm{~min}$ (Fig. 4), there was a significantly (P $<0.0005)$ enhanced efflux of insulin. Following return to perifusion with KRB containing $0.5 \mathrm{mg} / \mathrm{ml}$ glucose for $20 \mathrm{~min}$, islets were once again stimulated with $200 \mu \mathrm{g} / \mathrm{ml}$ NDS. The second stimulation also resulted in a significant $(\mathrm{P}<0.001)$ release of insulin which was greater $(P<0.005)$ than the release which occurred during initial stimulation.

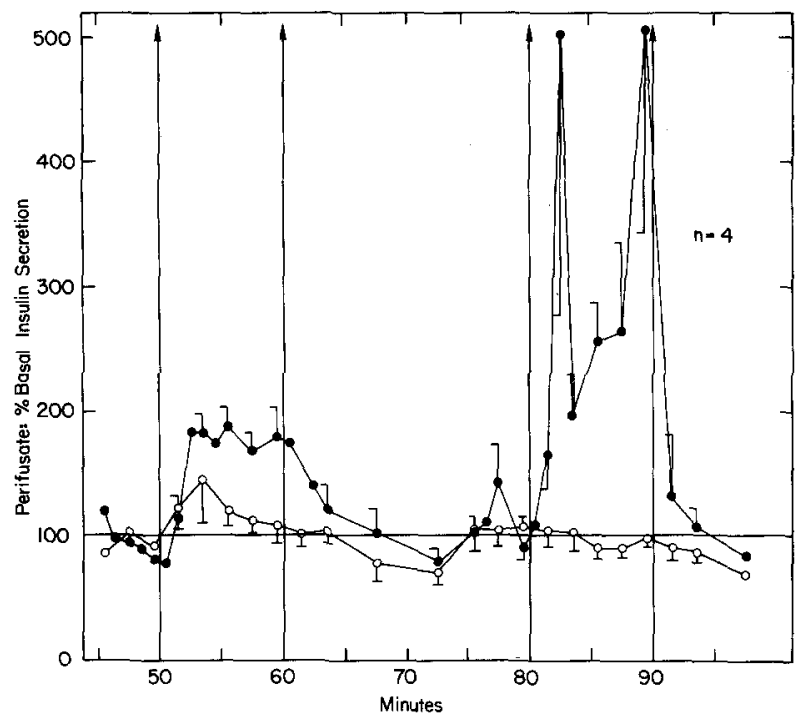

Fig. 4. Effect of repeated stimulation with naturally occurring diabetogenic substance (NDS) $200 \mu \mathrm{g} / \mathrm{ml}$. Double chambers were used. The control chamber $(\mathrm{O}-\mathrm{O})$ was perifused throughout with $\mathrm{KRB}-0.5 \mathrm{mg} / \mathrm{ml}$ glucose. The islets in the second chamber $(-)$ were exposed to NDS $200 \mu \mathrm{g} / \mathrm{ml}$ from 51 through $60 \mathrm{~min}$ and from 81 through $90 \mathrm{~min}$. During other time periods the second chamber was perifused with $\mathrm{KRB}-0.5 \mathrm{mg} / \mathrm{ml}$ glucose. Insulin release equivalent to $100 \%$ basal from the control chamber was $2.8 \pm 0.2$ and from the second chamber $3.1 \pm 0.2 \mu \mathrm{U} / \mathrm{ml} / \mathrm{min} / 25$ islets (mean \pm SEM). Four experiments were performed and each point is the mean of 4 values. Vertical bars indicate SEM

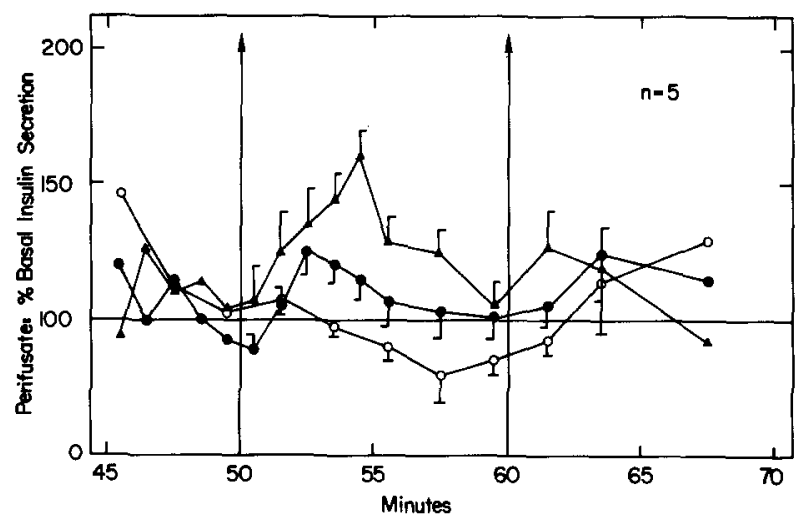

Fig. 5. Effect of subtilisin cleaved forms of hGH $\left(S_{1}\right.$ and $\left.S_{3}\right)$ on insulin release. Three chambers were simultaneously perifused with the control chamber $(\mathrm{O}-\mathrm{O})$ receiving $\mathrm{KRB}-0.5 \mathrm{mg} / \mathrm{ml} \mathrm{glu}-$ cose throughout. From 51 through $60 \mathrm{~min}$ the second chamber (-) was perifused with $S_{1} 200 \mu \mathrm{g} / \mathrm{ml}$ and the third chamber $(\boldsymbol{\Delta}-\mathbf{\Lambda})$ with $\mathrm{S}_{3} 200 \mu \mathrm{g} / \mathrm{ml}$. Insulin release equivalent to $100 \%$ basal from the control chamber was $8.4 \pm 0.9$; the second chamber, $6.9 \pm 0.8$; and the third $9.4 \pm 1.5 \mu \mathrm{U} / \mathrm{ml} / \mathrm{min} / 25$ islets (mean \pm SEM). Each point is the mean value from 5 separate experiments. Vertical bars indicate SEM 


\section{Insulin Release with Subtilisin Cleaved Forms $S_{1}$ and $S_{3}$}

As shown in Figure 5 both products produced by cleavage of intact hGH with subtilisin appeared to induce insulin release. However only the response to $200 \mu \mathrm{g} / \mathrm{ml} \mathrm{S}_{3}$ was significantly greater $(\mathrm{P}<0.0005)$ than that found in the control.

\section{Determination of Insulin Antibody Crossreactivity with Growth Hormone Preparations and Naturally Occurring Diabetogenic Substance}

Solutions containing each of the proteins studied $(200 \mu \mathrm{g} / \mathrm{ml})$ were assayed for immunoreactivity by the insulin radioimmunoassay, described above. An average of $1.0 \mu \mathrm{U} / \mathrm{ml}$ insulin-like activity was detected in each $0.1 \mathrm{ml}$ aliquot of KRB containing 20 $\mu \mathrm{g}$ of a single pituitary protein. One type of pituitary protein did not show significantly more insulin-like activity than another.

\section{Discussion}

This study suggests that clinical grade hGH can elicit an immediate release of insulin from islets obtained from hypophysectomized rats at a low ambient glucose concentration. However, purified intact hGH did not stimulate insulin secretion. Since clinical grade hGH is a mixture of several proteins [8], its ability to induce insulin release is probably due to some other protein(s), such as NDS, rather than to intact hGH.

Naturally occurring diabetogenic substance appears to act directly on islets to induce the prompt release of insulin. Because of the rapidity of the response, it seems unlikely that the in situ generation of somatomedin is responsible for the action of NDS [1]. Also, since the medium concentration of glucose was $0.5 \mathrm{mg} / \mathrm{ml}$, it is unlikely that intra-islet glucagon release is responsible for insulin release [15]. In nanogram quantities, NDS can induce insulin release. After a single $10 \mathrm{~min}$ exposure, NDS does not appear to have a toxic effect on islets since repeat stimulation results in a significantly greater release of insulin. Although the enhanced insulin release during the second stimulation may simply reflect islet adaptation to perifusion conditions, it is also possible that the initial exposure to NDS enhanced the cellular mechanisms involved in the release of insulin.

At this time the structure of NDS is unknown. We have suggested that it is a distinctly different protein from hGH in that it may be an enzymically modified form of hGH. Subtilisin cleaved forms of intact hGH, $S_{1}$ and $S_{3}$, induce hyperglycaemia and hyperinsulinaemia in the dog [8]. Only the $S_{3}$ preparation at $200 \mu \mathrm{g} / \mathrm{ml}$ elicited a significant insulin response. In this regard, both $S_{1}$ and $S_{3}$ are less potent than NDS but are more potent than intact hGH. The functional similarity of enzymically modified forms of $\mathrm{hGH}$ and NDS also may suggest structural similarity.

Acknowledgements. These studies were supported by Grants Nos. HL-20517, AM-09537, AM-16065, AM-21 290 and RR-05 514 awarded by the National Institutes of Health and by an award from the Kroc Foundation. This is Publication No. 11 from the Lutcher Brown Center.

\section{References}

1. Tai, T.-Y., Pek, S.: Direct stimulation by growth hormone of glucagon and insulin release from isolated rat pancreas. Endocrinology 99, 669-677 (1976)

2. Malaisse, W. J., Malaisse-Lagae, F., King, S., Wright, P. H.: Effect of growth hormone on insulin secretion. Am. J. Physiol. 215, 423-428 (1968)

3. Coore, H. G., Randle, P. J.: Regulation of insulin secretion studied with pieces of rabbit pancreas incubated in vitro. Biochem. J. 93, 66-78 (1964)

4. Grodsky, G. M., Bennet, L., Batts, A., McWilliams, N., Vcella, C.: Insulin secretion from isolated perfused pancreas. Fed. Proc. 21, 202 (1962)

5. Bouman, P. R., Bosboom, R. S.: Effects of growth hormone and of hypophysectomy on the release of insulin from rat pancreas in vitro. Acta Endocrinol. (Kbh.) 50, 202-212 (1965)

6. Lewis, U. J., Singh, R. N. P., Peterson, S. M., VanderLaan, W. P.: Human growth hormone: A family of proteins. In: Growth Hormone and Related Peptides, Proceedings of the III International Symposium, pp. 67-74, International Congress Series No. 381. Amsterdam: Excerpta Medica 1975

7. Kostyo, J. L., Wilhelmi, A. E.: Conference on the structurefunction relationship of pituitary growth hormone: A report. Metabolism 25, 105-124 (1976)

8. Lewis, U.J., Singh, R. N.P., VanderLaan, W.P., Tutwiler, G. F.: Enhancement of the hyperglycemic activity of human growth hormone by enzymic modification. Endocrinology 101, 1587-1603 (1977)

9. Lacy, P. E., Kostianovsky, M.: Method for the isolation of intact islets of Langerhans from the rat pancreas. Diabetes 16, 35-39 (1967)

10. Lacy, P. E., Walker, M. M., Fink C. J.: Perifusion of isolated rat islets in vitro. Participation of the microtubular system in the biphasic release of insulin. Diabetes 21, 987-998 (1972)

11. Freinkel, N., El Younsi, C., Bonnar, J., Dawson, R. M. C.: Rapid transient efflux of phosphate ions from pancreatic islets as an early action of insulin secretagogues. J. Clin. Invest. 54, 1179-1189 (1974)

12. Hartree, E. F.: Determination of protein: A modification of the Lowry method that gives a linear photometric response. Anal. Biochem. 48, 422-427 (1972)

13. Morgan, C. R., Lazarow, A.: Immunoassay of insulin: Two antibody system. Diabetes 12, 115-126 (1963)

14. Ostle, B.: Statistics in Research, pp. 310-311. Ames, Iowa: The Iowa State University Press 1963

15. Malaisse, W. J., Malaisse-Lagae, F., Mayhew, D.: A possible role for the adenylcyclase sytem in insulin secretion. J. Clin. Invest. 46, 1724-1734 (1967)

Received: December 19, 1977,

and in revised form: March 28, 1978

Dr. B. A. Larson

Lutcher Brown Center for Diabetes and Endocrinology

Scripps Clinic and Research Foundation

10666 North Torrey Pines Road

La Jolla, CA 92037

USA 